\title{
A prospective model for aligning educational quality and student experience in international higher education
}

\author{
Vangelis Tsiligiris ${ }^{a}$ and Christopher Hill ${ }^{b}$ \\ ${ }^{a}$ Nottingham Business School, Nottingham Trent University, Nottingham, UK \\ ${ }^{\mathrm{b}}$ The British University in Dubai, UAE
}

\begin{abstract}
The aim of this paper is to develop a model that addresses and bridges the gap between quality management and student experience. The model incorporates the most commonly occurring systems, namely: quality control; quality assurance; quality audit; quality assessment; quality enhancement; and quality management. The paper highlights the key elements of these approaches and constructs a model that provides a more comprehensive tool for accurately implementing and measuring quality in international higher education. The model, as a proposed conceptual framework, can be used by managers in Transnational Education (TNE), both at home and host institutions, to facilitate improvements in the TNE student experience while at the same time meet wider institutional objectives about educational quality.
\end{abstract}

Keywords: new managerialism; student experience; quality management; transnational education; internationalisation

\section{Introduction}

The measurement and management of quality in higher education is an issue of debate, which has resulted in a flux of methods and approaches. The increase in the volume and types of TNE activities has initiated a growing interest and focus on quality. This increase has led to the development of understanding in key areas but there remains a necessity to connect elements of the process more coherently. The aim of this paper is to develop a model that addresses and bridges the gap between quality management and student experience. The model will take into account the most commonly occurring systems, namely: quality control; quality assurance; quality audit; quality assessment; quality enhancement; and quality management. The paper will identify the key issues of these approaches and construct a model that provides a more comprehensive tool for accurately implementing and measuring quality in international higher education.

Quality control is a system which replicates manufacturing production standards systems. It focuses on checking whether higher education services have achieved desired standards. This control takes place at the very final stage of production and is usually performed by an external individual or organisation. Quality assurance is about the assurance to 
stakeholders that the provision fulfils certain standards. Here, the fulfilment of standards can range from matching minimum thresholds to meeting the expectations of internal or external stakeholders (Harvey 2012). However, this has been predominately pursued by external stakeholders, mainly quality assurance bodies such as the Quality Assurance Agency (QAA) in UK, as a means to assure minimum required standards, rather than quality enhancement (Filippakou 2011). Quality audit is a process of assuring that strategic objectives deriving from the mission statements of HEls, in regard to teaching and learning, are accomplished. Quality audits are conducted by external bodies. Quality assessment refers to a process of quality evaluation which involves comparing the actual performance of HEls against a set of benchmarks/criteria derived either from the institutions' mission statements or from international standards (Tam 2001). This process can be implemented by internal or external bodies. Quality enhancement is about improvement. This, mostly, manifests in an effort by HEls to improve teaching quality via staff development practices. The problem with this approach is that it usually leads to qualitative and non-measurable outcomes.

Quality Management is the process, supported by policies and systems, used by an institution to maintain and enhance the quality of the education experienced by its students and the research undertaken by its staff. We discuss this last as we believe it encapsulates all the others: that is, quality management seeks to assure and enhance quality using an expectations-perceptions model. This implies that the management of quality will aim to bridge the space between the expectations of the various stakeholders, including students and external quality assurance bodies, and the perceptions of these stakeholders of the outcomes/product of the provision. This is explained by Milisiunaite, Adomaitiene, and Galginaitis $(2009,67)$ : quality management "covers all activities that ensure fulfilment of the quality policy and the quality objectives and responsibilities and implements them through quality planning, quality control, quality assurance, and quality improvement mechanisms".

While several international organisations (e.g. UNESCO) and national agencies in exporting and importing countries (e.g . QAA in the UK; Malaysian Qualifications Agency in Malaysia) have developed quality assurance (QA) guidelines focused on TNE activities, in practice most of the attention in managing quality across borders has been on assurance (Smith 2010), which is articulated by two main objectives: 1) minimising the risks, reputational and economic, for exporting countries and institutions, and 2) offering consumer protection for students and their families. Overall, it is widely accepted that the focus of existing quality policies and systems in TNE has been overly focused on assuring minimum required standards rather than actively seeking to manage quality under its meaning of 'fit for purpose'.

Quality management in TNE is influenced by three elements: 1) the exporting country's quality assurance guidelines, 2 ) the importing country's quality assurance guidelines, and 3) the guidelines of good practice proposed by international bodies. However, extensive evidence shows that quality assurance in TNE is dominated by the guidelines of exporting countries (Smith 2010; Tsiligiris 2015). 
Additionally, the focus of the existing quality assurance guidelines has been subject to debate. Some argue (Van der Wende and Westerheijden 2001) that these guidelines are necessary to maintain and reassure the status of awards and the reputation of higher education institutions worldwide, thus arguing for the replication of the 'home' institution standards offshore. Others (Stella 2006) argue that quality assurance guidelines for offshore education should also reflect the cultural and contextual aspects of the importing country. This debate is central to the purpose of this study, which aims to justify the philosophical as well as the practical reasons which explain why the replication of the exporting country's student-as-customer model is neither possible nor appropriate for managing quality in a TNE and, more widely, an international HE setting.

\section{Literature Review}

The section starts with the consideration of the prevailing quality discourse in higher education which is shaped by new managerialism, the emphasis on value for money, and the view of students as customers. Expanding from this, the section outlines the key characteristics and shortcomings of the services quality customer model and introduces educational quality as more effective in addressing the priorities of the prevailing quality discourse in higher education. Using Biggs' (2001) prospective approach for the management of quality in higher education, the section concludes with the theoretical framework behind the proposed prospective quality management model in TNE.

\section{Current quality discourse in higher education}

\section{New managerialism}

Despite the existence of various definitions about quality in higher education, there appears to be a range of dynamics that affect the ideological and practical elements of quality in higher education at any particular point in time. As Filippakou (2011) argues, the current quality discourse is shaped by wider prevailing political and economic ideologies. These ideologies will shape the meaning of quality and drive policy objectives. An important implication emerging from the view of quality as discourse is that quality, both as a meaning and as a policy objective, will be subject to the wider socio-economical beliefs which dominate each particular setting at each particular moment in time. Considering this in a TNE context, one can understand that the applicability of quality not only has practical difficulties, due to varying student characteristics, but can also be ideologically incompatible across different countries. In the UK, a major TNE exporting country (Universities UK 2018), the current quality discourse is driven by neo-liberalism, also the prevailing ideology underpinning society and the economy in most exporters of TNE (Zajda and Rust 2016), and explains why the current view is shaped by the 'student as customer' approach.

Under new managerialism, managerial control and involvement were central in the effort to respond to the two main objectives, the increase of efficiency (excellence school), and the reduction of cost with the increase of output (Neo-Taylorist) (Politt and Baichaert 1995). Critical to this research is the rise of accountability and performance measurement as 
inherent parts of the operational management of public sector organisations. This is relevant because the call for accountability and performance measurement is considered the starting point for the adoption of quality management practices in the public sector, in particular in higher education (Jarvis 2014).

The main components of new managerialism affect and shape quality in higher education, both at home and offshore in a TNE context. Under this public management approach, quality in higher education is pursued within a context of accountability, achieved through specific quantitative goals, targets, and indicators. This is articulated by the fact that new managerialism considers the users of public services, such as higher education, as customers who have rights, and should be treated as such (Milliken and Colohan 2004, 382). This justifies the nature of the current quality management approach in major exporting countries such as the UK.

There has been extensive criticism of the appropriateness of new managerialism approaches in higher education in the context of extensive government intervention and neglect to maintain academics as an important part of efforts to improve the quality of teaching and learning (Lynch 2015; Naidoo and Williams 2015). Overall, there seems to be a consensus that new managerialism is considered inappropriate to drive quality management in higher education, primarily due to insufficient, or irrelevant, measures for capturing complex dimensions and elements of the educational process.

\section{Higher Education Institutions (HEls) as service providers and students as customers}

Alongside new managerialism, the marketization of higher education and the view of students as customers, have had a significant impact on public policy for quality management in $\mathrm{HE}$ and therefore, are particularly relevant to this study. These developments are driven by a variety of factors that merit further analysis.

Firstly, the government has actively and persistently introduced the idea of students as customers (Williams 2012). For example, Sam Gyimah MP, UK Minister for Higher Education, in a speech titled "A Revolution in Accountability" (2018) states "gone are the days when students venerated institutions and were thankful to be admitted. We are in a new age the age of the student". He continues to argue that "what may feel to some in the sector like a revolt is more like a revolution - a revolution pushing the sector towards greater responsibility and accountability to students". This viewpoint, clearly outlines students as customers whose ability to judge quality is paramount not only to the operation of the higher education sector but, surprisingly, for its quality assurance. That is despite the extensive criticism as to whether students are able and qualified to judge quality (Balloo, Pauli, and Worrell 2017; Elassy 2015; Hall, Swart, and Duncan 2012). Overall, literature (Douglas et al. 2015; Appleton-Knapp and Krentler 2006; Jungblut, Vukasovic, and Stensaker 2015) suggests a drive towards 1) a quality assurance approach with drive for accountability and 'value for money' at its core, and 2) the view that students are customers who must therefore be considered as rational individuals (see Figure 1). 
Secondly, the global increase in demand for higher education has intensified the competition between HEls and led to the adoption of marketing practices which claim 'value for money' and differentiation by making various claims about unique value customer propositions (Lynch 2006; Molesworth, Scullion, and Nixon 2010; Cardoso, Carvalho, and Santiago 2011).

The above two dynamics explain the rise of students adopting a customer-minded approach as soon as they begin considering options for higher education. Students are encouraged by the government to look for relevant information and compare higher education providers using specific indicators, like national student survey results (e.g. NSS ${ }^{1}, \mathrm{PTES}^{2}$ ) and university rankings (e.g. TEF $^{3}$ ). In the UK this reveals a tendency to focus on outcomes as indicators of quality and to assume students, or prospective students, are able to judge quality in higher education. This clearly underlines a shift towards a customer model in higher education which has a range of implications, particularly on quality management in UK as a TNHE exporting country, discussed later in this paper.

In addition to neo-liberal influenced policy shifts, the increased requirement for knowledgeable workers from so-called knowledge-based capitalism has contributed to the marketisation of higher education and its evolution as a service, and the student as customer. The basic principles of new managerialism and service quality have transformed quality in higher education to be a function of the factors of 'value for money' and 'students as customers'. Therefore, irrespective of how one defines quality in higher education, the central policy direction and the current quality discourse have at their core the customer model. Student service expectations and perceptions play a central role in managing quality, particularly in relation to student experience, in the contemporary higher education context. Today students are increasingly considered by both the government and HEIs as customers, who vindicate their desires and rights via student satisfaction surveys or/and other feedback systems in pursuit of 'value for money'.

\footnotetext{
${ }^{1}$ The National Student Survey in the UK.

2 The Postgraduate Teaching Experience Survey in the UK.

${ }^{3}$ Teaching Excellence Framework.
} 


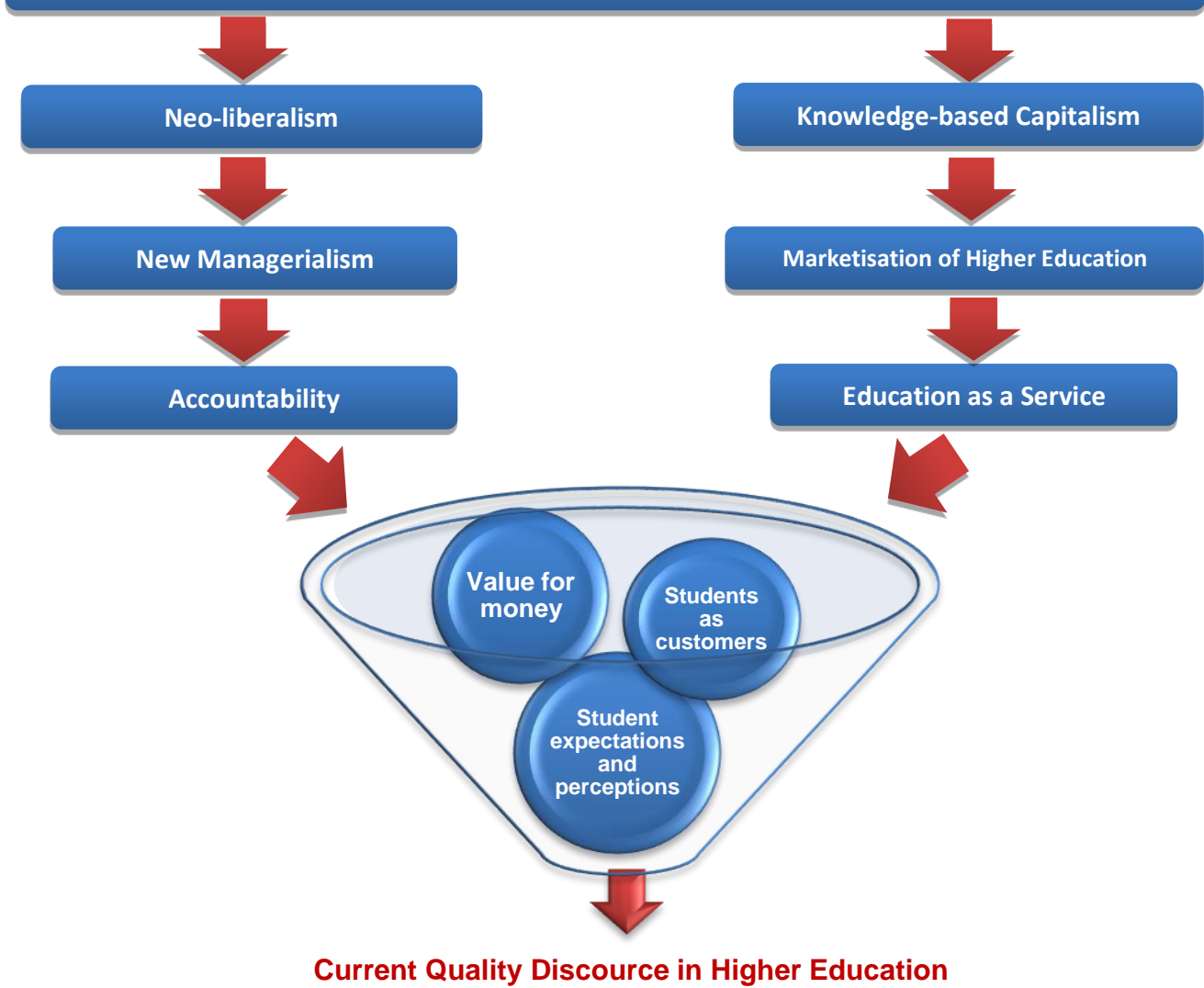

Figure 1: Current quality discourse in higher education

\section{Service quality and the customer model in higher education}

Whichever the approach or system, the main objective of contemporary higher education policies, especially in TNE exporting countries, is to manage quality in an effort to increase student satisfaction and gain or maintain competitive advantages (Hussey and Smith 2010). Student satisfaction ratings have become a barometer of service quality in education and is used by HEls in their pursuit for competitive advantage (Rondey Arambewela and Hall 2006; Sadeh and Garkaz 2015). Overall, service quality management calls for the alignment of customer expectations with customer perceptions, and/or considers perceptions as indicating of the conferment of quality (Adee Athiyaman 1997; Barnes 2007; Bebko 2000; Ekström, Liu, and Beljulji 2011). Consequently, despite the varied conceptualisations about the measurement of service quality, there is a consensus about the role of expectations and perceptions in service quality measurement (Abdullah 2006). This has created an increased focus on the customer model - the expectations-perceptions model - for managing quality in higher education. While customer satisfaction plays an increasing role in service quality. Service quality and customer satisfaction are two different, but inter-related, concepts (Tsoukatos and Rand 2007). Additionally, as the review of the literature indicates the alignment of expectations and perceptions is a key determinant of customer satisfaction (Tsoukatos and Rand 2007, 469). 
The expectations-perceptions gap theory, which measures service quality as a function of the difference between expectations and perceptions, dominates the quality management systems in higher education. The gap theory implies that service providers should do what they promise to do (Zeithaml, Berry, and Parasuraman 1993). This is relevant for higher education for two further reasons: first, as an effort to assure the accountability of the higher education providers; and second as a 'value for money' view of quality".

The applicability of the service quality model to higher education is debatable and has been the issue of many studies and publications by a wide range of stakeholders (Cheng 2011; Hussain and Birol 2011; Bebko 2000; Zhao 2012). The main line of criticism is around two issues: First, whether student expectations should be the benchmark for higher education providers, on the grounds that students are not able to set the standards for higher education (Wiers-Jenssen and Stensaker 2002). This reflects a view of quality as a top-down concept. Second, that students' perceptions are affected by satisfaction, which should not be an indication of good quality higher education, since the educational process should not always be enjoyable for students (Letcher and Neves 2010).

Despite this on-going debate about the appropriateness of the conceptualisation of students as customers and of HEls as service providers, the service quality paradigm remains dominant in higher education quality management (Pratasavitskaya and Stensaker 2010; Williams 2012). This falls within the quality discourse presented earlier, driven by calls for accountability and value for money.

\section{Educational quality}

Despite the prevalence of the view of HE as a service and students as customers, it is argued that HE has distinct characteristics which separate it from other services (Quinn et al. 2009). The literature shows agreement on the separation between educational and non-education processes/services in higher education. The former concerns the actual education-related activities and processes, such as teaching, assessment and attainment. The latter concerns the services provided to students outside the educational process, such as administration, student support services and recreation. Overall, there appears to be a consensus among the different stakeholders about the value of educational quality as an indicator of quality in higher education (OECD 2009; Biggs and Tang 2011).

Considering the central role of education quality in student experience, in the next section we define and the describe the 3P model by Biggs $(1988,1989)$. This model explains learning

\footnotetext{
${ }^{4}$ Potentially, this could lead to increased attention by HEIs, governments and researchers to go beyond the measurement of service quality in higher education to explore and understand student expectations and perceptions. Nevertheless, as will be discussed later in this paper, the existing quality management models appear to focus only on the measurement of service quality outcomes, summarised under the term "the student experience". For example, in the UK, the National Student Survey (NSS) focuses on student satisfaction and service quality indicators, while the Key Information Set (KIS), introduced in 2012, is criticised for promoting standardisation (Davies 2012).
} 
as subjective process which is influenced by a range of different factors that are specific to each particular context of delivery. This is highly relevant to the development of our conceptual framework as it creates a link between student factors, including expectations and perceptions, and education process outcomes.

\section{The educational process - Biggs 3P model}

Biggs (1993) identifies that the educational process consists of three stages, the presage, the process and the product; this is known as Biggs' 3P model (figure 2 below). Biggs's model is central to the purpose of this paper, as it justifies the value of exploring and understanding student expectations and perceptions as early as possible the students' academic journey. In Biggs' model there appears to be a relationship between the so-called presage variables and the process and product variables. This implies that the actual educational process and product (outcome) will be subject to the specific presage variables.

The presage stage refers to the student context and the teaching context. The student context includes prior knowledge, expectations, preferred ways of learning, values, motivation, and abilities. The teaching context includes the course structure, curriculum and teaching and assessment methods. Students, on entering the education process, bring with them habits and predispositions which directly affect the education process (Biggs 1988, $1993,1996)$. This is of critical importance for this research, as it justifies the fact that student factors, beyond expectations, would not be the same across different settings of delivery. Thus, in a TNHE context the replication of the home institution learning process would be subject to student factors in the partner institution.

The process refers to the actual approach to learning which, according to Biggs' (1993) theory, is not fixed but is subject to the student and teaching contextual characteristics. This means that the learning approach will be the outcome of the combination of the student and teaching contexts and will range from deep to surface learning. This explains that the effectiveness of adopting the deep learning approach, pursued by UK HEIs in their home and TNE provision, will depend upon student characteristics and the teaching context. The latter is controlled by the awarding institution through validation of the teaching and learning infrastructure. However, the impact of student characteristics on the learning approach adopted by students is rarely explored in a TNE setting, which justifies the value of this paper.

The product refers to the learning outcomes after the completion of the teaching and learning process. This part attracts most of the attention of external and internal stakeholders as it often articulated in module grades, degree classifications and other key attainment statistics. There is an over-concentration on measuring outputs at the end of the academic cycle and planning corrective actions based on past performance. However, very little consideration is undertaken about the proactive management of the previous stages of 
the education process which appear to have a direct impact on education process outcomes.

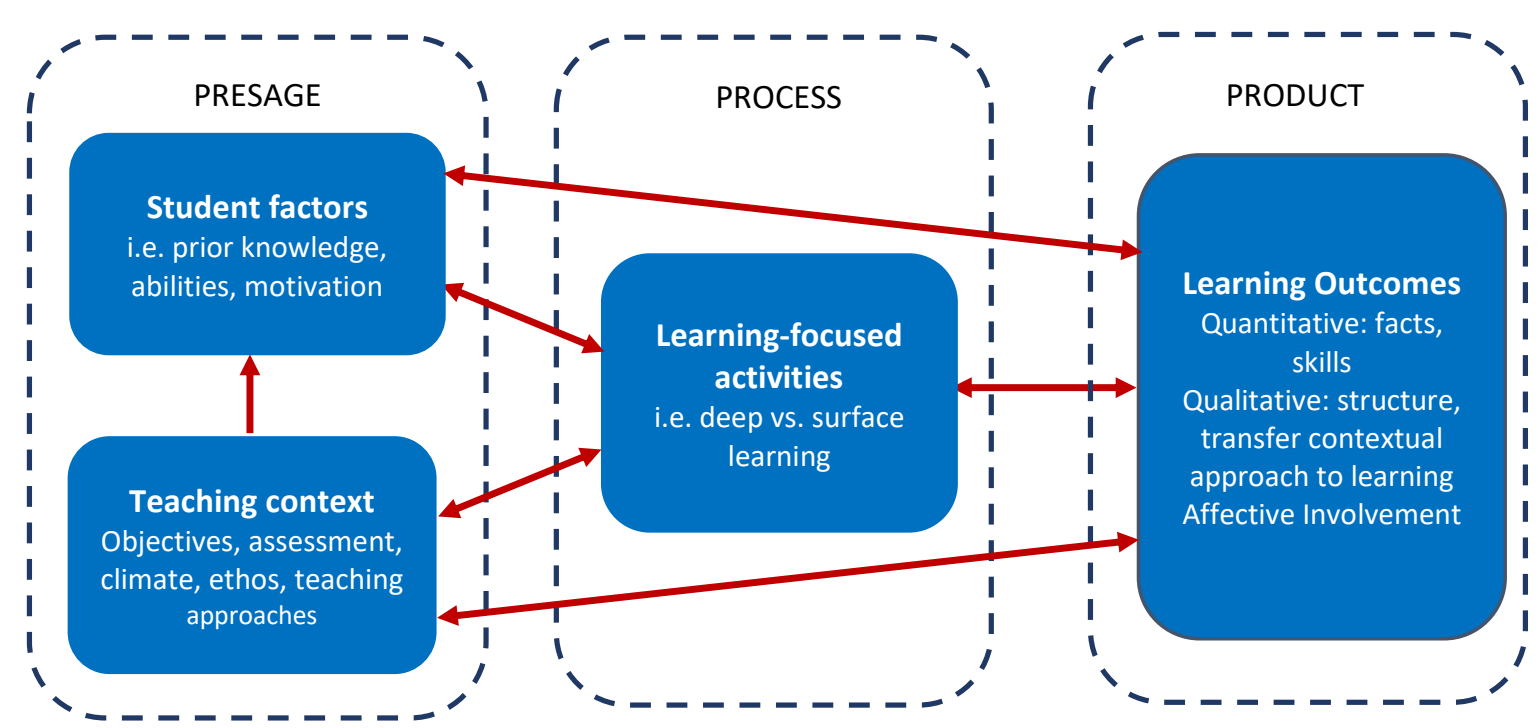

Adapted from Biggs (1996, p. 62)

Figure 2: Biggs 3P model

From the discussion of the key attributes of 3P model it is clear that student related presage dimensions relate directly to educational quality and, to a large extent, determine the learning approach adopted by students. This implies that the efficiency of the teaching and learning practices pursued by an institution would not lead automatically to the desired results but would, rather, depend upon the individual student presage variables.

\section{Link between educational quality and student experience}

Although several authors consider educational quality to be incompatible with service quality in higher education, research indicates a clear link between the two. Specifically, as outlined in figure 3 below, existing research has shown that student expectations and perceptions are affected by various student presage factors, such as country of origin, individual values, and previous education schooling experience (Hill 1995; Green 2014; Telford and Masson 2005). Unrealistic, or incompatible, expectations, as student presage factors, will affect the learning approach adopted by students (i.e. surface vs. deep) and adversely impact the learning outcomes. In turn, and as research indicates, students who have not achieved the expected educational outcomes would be less satisfied with their student experience. Thus, the educational process - as a distinct but inseparable part of the higher education service function - influences the perceived student experience by students. Thus, the exploration and active management of student presage factors will be of critical importance for both service and educational quality.

Under the service quality paradigm, the better customers' expectations and values are understood and interpreted, the better the results in managing quality (F. M. Hill 1995; Sander et al. 2000). Consequently, it is possible for higher education institutions to manage 
concurrently the educational and service quality by exploring, managing and meeting student expectations at the time that or before students enter the university (Kay, Dunne, and Hutchinson 2010; Gibson 2010). This aligns with the conceptualisation of quality by Finnie and Usher $(2005,19)$ which can be summarised as "...the value added of educational experience, whereby 'higher quality experiences' are those that result in superior learning outcomes, and better final outcomes". And it is the input factors/dimensions that affect outcomes.

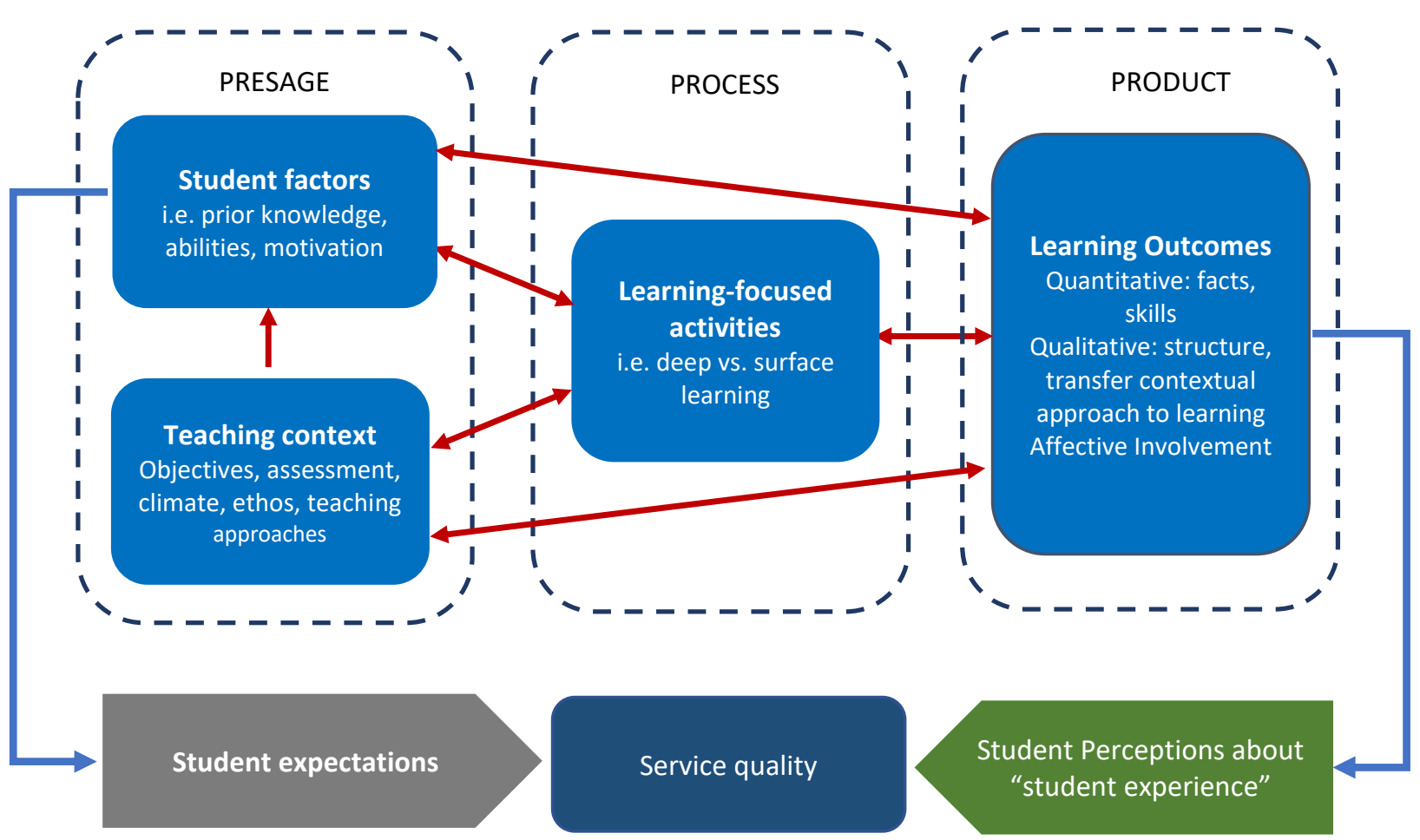

Figure 3: How education quality links with the student experience

\section{Educational quality management: Retrospective vs. prospective approach}

Considering the interdependency of presage, process and product variables in the educational quality process, the question is how educational quality is managed in the context of the current quality discourse in higher education, and more widely in TNE. The current quality management model is best described by what Biggs (2001) calls the 'retrospective' quality management approach. According to Biggs (2001), the retrospective quality approach focuses on comparing outcomes with specific thresholds and considers quality as 'value for money' while it focuses on meeting external stakeholders' needs. The priorities in this approach are managerial, and quality is considered as a top-down process. The retrospective approach focuses at the end results and "looks-back back to what has already been done" (Biggs 2001, 222). In the context of educational quality, a retrospective approach takes student presage factors as fixed and assumes that these are going to be adapted to those required in order for the institutional teaching and learning approach to function. This is best articulated by Biggs (2001, 222), who argues that despite retrospective 
quality management being pictured as concerned with quality as 'fit for purpose', "the procedures adopted address 'value for money', and are frequently counter-productive for quality in the sense of providing rich teaching contexts and enhanced learning outcomes".

Biggs (2001) introduces the term 'prospective' quality management as an alternative to retrospective quality management. The prospective quality management approach considers quality as fitness for purpose and the educational process as transforming while its priorities are educational. Under a prospective management approach, Biggs (2001) argues, quality is considered as a bottom-up process pursued within the context of institutional mission and objectives. This bottom-up process implies a quality management approach which is reflective of student characteristics (i.e. presage factors), and not a quality management approach that is designed by students themselves. Interestingly Biggs' prospective management approach complies with the calls by several bodies and authors (UNESCO and Council of Europe 2001; Browne 2010; IIEP-UNESCO 2011; Williams 2018) for the need for quality systems to be reflective of student characteristics and to focus on quality aspects related to teaching and learning.

Considering the significant impact of student presage factor on educational and service quality outcomes (Nijhuis 2006; De la Fuente et al. 2011; Ginns, Prosser, and Barrie 2007; Smimou and Dahl 2012), a prospective approach appears to be more appropriate than a retrospective one in addressing the needs of the various stakeholders, including students (Biggs, 2001). This is because the prospective approach focuses on eliminating problems before they occur by reflecting on the different student presage factors. In this context, the prospective approach can be considered as the best way to combine the fulfilment of the educational and service quality standards required by TNE exporting countries, with the desired contextualisation which is currently absent in TNE (Bolton and Nie 2010; Farrugia 2012).

The retrospective vs. prospective conceptualisation in quality management is particularly relevant to this study, because it provides the theoretical framework to evaluate the applicability of the existing customer model for the management of quality in TNE. Also, it provides a framework within which future research could evaluate the adoption of a prospective model in the management of quality in TNE. Most importantly it supports the alignment of service and educational quality responsive to specific contextual factors (i.e. culture, education system) and student presage factors (i.e. previous knowledge, expectations and perceptions about quality) in different programme delivery locations.

\section{The current retrospective model for managing quality in TNE}

The framework presented in Figure 3, below, summarises the main themes as they emerge from the literature review and structures them around an emerging key research question and problematizes TNE from the relationship between quality management and student experience and seeks to address traditional approaches in light of current expectations and 
structures. . At the top of the framework is the current quality discourse in higher education, which is articulated via a drive for value for money and quality as fit for purpose. This, along with the development of the marketisation of higher education, has contributed to the dominance of the concepts of 'student as customer' and 'higher education institutions as information providers' (Williams 2012; Brown and Carasso 2013; Molesworth, Scullion, and Nixon 2010; Lynch 2006). This has led to an over-concentration on the use of student satisfaction surveys as a means to measure quality, which is primarily linked to the prevalence of service quality in higher education quality management.

A retrospective approach is the prevailing quality management model in higher education today. As summarised by Biggs' (2001), this approach considers quality as top-to-bottom process and focuses on measuring the end results - particularly student satisfaction and attainment - with the use of managerial practices while being non-reflective of student characteristics. In a TNE context, the objectives of the existing quality management approach are identified as risk-mitigation and equivalency. These objectives are achieved primarily via the use of the exporting country's quality assurance guidelines, which has been identified as retrospective and customer focused. The pursuit of TNE quality management with the use of a retrospective customer model designed at the 'home' institution carries the assumption that such a quality model can be replicated across borders without considering the impact of differences in student factors or considering them as fixed. However, the literature review findings indicate that student factors, including expectations and perceptions about quality, are individual and context-bound. Thus, the existing quality management model in TNE implies problems in the reassurance of educational as well as service quality standards across different locations of programme delivery.

The problematic nature of the applicability of a rigid customer model to manage quality across borders is articulated excellently by Fallshaw $(2003,2)$, who argues that "when programmes are designed in one place and delivered in another country, ensuring quality can become problematic". This is justified on the basis of the diversity of organisational forms and structures of higher education institutions, the various cultural settings, the types of transnational partnerships, and the differences in the conceptualisation and measurement of quality (Fallshaw 2003; Coleman 2003; Chapman and Pyvis 2013). Primarily, what makes quality management across borders a challenging process is the vast differences in the quality expectations and perceptions of various stakeholders, including the students (Lim 2008). This is confirmed by the findings of relevant research (Wilkins, Stephens Balakrishnan, and Huisman 2012; Stella and Bhushan 2011), showing that different stakeholders, including students, hold different expectations from, and perceive quality differently in, transnational higher education partnerships.

Considering the variability of student presage factors (Hill, Lomas, and MacGregor 2003; Wallace and Dunn 2013; Ginns, Prosser, and Barrie 2007; Min, Khoon, and Tan 2012), the applicability of the retrospective customer model for the management of quality in TNE 
could be considered rather problematic in relation to its effectiveness regarding educational quality outcomes. Surprisingly, the need to explore student expectations and perceptions seems to be muted in the discussion about quality management in TNE. Instead, the review of the quality assurance guidelines reveals a focus on equivalency of standards without exploring how this can be achieved by considering the importance of student presage factors on the effectiveness of the educational process, as discussed by Biggs (1993), Gibbs (2010, 2012), and Finnie and Usher (2005).

Taking into account that student satisfaction is a function of the expectations-perceptions gap (Browne et al. 1998; Stukalina 2012; Gruber et al. 2010), a difference in student expectations across different student cohorts (e.g. 'home' students and 'offshore' students) who study on the same programme, may be a source in itself of differences in student satisfaction between these cohorts. This will impact the effectiveness of the retrospective customer model to manage service quality in TNE. At the same time, student satisfaction is also associated with educational quality. Research has shown (Lizzio, Wilson, and Simons 2002; Nijhuis 2006; De la Fuente et al. 2011) that students with inappropriate expectations which are unlikely to be met by the existing provision if left unmanaged, usually end in poor educational outcomes and this in turn results in poor levels of student satisfaction. However, a great body of literature, not only higher education related, reveals a great discrepancy in factors that influence customer decision-making, primarily in the service sector (Cronin Jr, Brady, and Hult 2000; Sheth, Mittal, and Newman 1999). This implies a range of challenges for the applicability of retrospective quality management in TNE, owing to the fact that different students would be influenced by different factors during their customer decision-making process (Maringe and Carter 2007; Moogan and Baron 2003). It is very likely, therefore, that students as customers who choose to study in TNE programmes will be influenced by different factors to those of students who decide to study at the main campus of the exporting institution. This in turn may imply a range of challenges for both the exporting and the importing institution in regard to the applicability of a retrospective customer model for the management of quality. As a result, a deeper appreciation for the constraints in place, and an awareness of the emerging needs and requirements, provides the ability to construct a tailored approach.

For the above reasons, the applicability of a common retrospective model for the management of quality in TNE thus appears to be problematic. Thus, an exploration of factors that affect student choice, as well as student expectations and perceptions about quality in higher education, would be important in evaluating the applicability and appropriateness of a retrospective customer model for the management of quality in TNE. Also, the key research question which arises from the above discussion is: What alternative model, taking differences in student presage factors into account, would allow the effective and concurrent management of educational and service quality in TNE across borders? 


\section{Current quality discourse in $\mathrm{HE}$}

- Quality as value for money and fit for purpose

- Students as customers and HEls as information and service providers

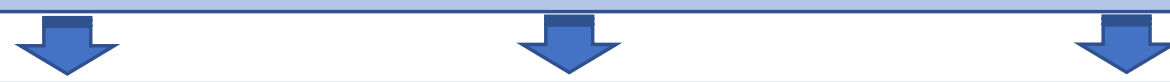

\section{Current quality management approach in HE}

- Dominance of customer model of service quality in higher education

- Consensus about the importance and relevance of educational quality but use of retrospective quality management (Biggs 2001) with emphasis on student perceptions and satisfaction.

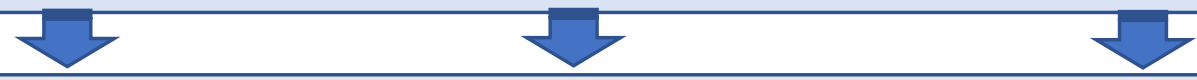

\section{Current quality management model in TNHE}

- Dominance of the quality management approach of the exporting country

- Quality assurance as risk mitigation

- Focus on equivalency rather than enhancement

\section{The current approach assumes / implies}

Student expectations (presage) are the same across the different locations of delivery
Student perceptions about quality in higher education, both as term and as set of desired outcomes, are the same across different locations of delivery

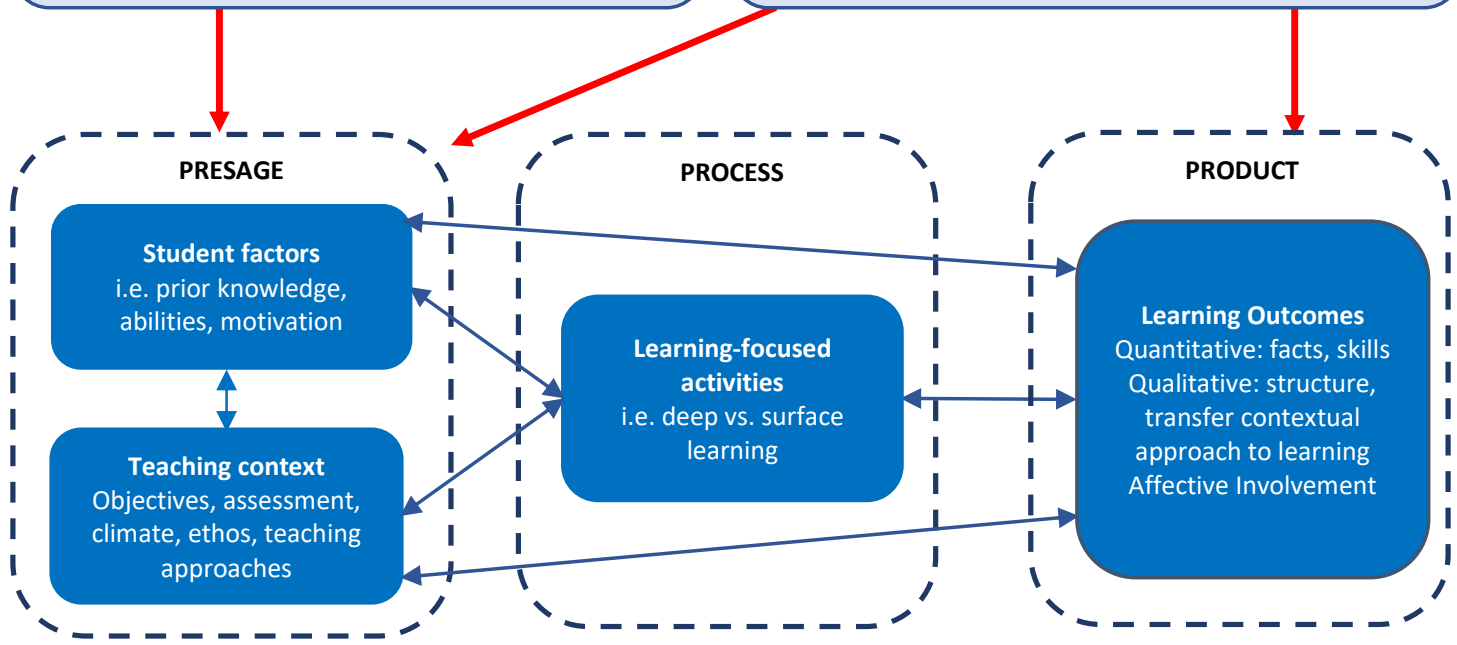

Research problem

What would be an alternative model which, by considering the differences in student presage factors, will allow the effective and concurrent management of educational and service quality in TNE across borders?

Figure 4: Current retrospective model for managing quality in TNE 
A prospective model for aligning educational quality and student experience in TNE

To address the constraints of the existing quality management approach in TNE, we propose a conceptual framework that utilises 1 ) the 3P Biggs model, 2) the service quality gap model and 3) the Biggs prospective management approach. Additionally, the conceptual framework reflects on literature review findings around the nature of student expectations and perceptions about quality.

The ultimate objective of the proposed conceptual framework is to aid the identification of those inputs that lead to better educational and service quality outcomes in a TNE context. Combining the 3P Biggs model and the service quality gap model, in the context of Bigg's prospective quality management approach, facilitates the concurrent management of educational quality and student experience.

As shown in Figure 5 below, our conceptual framework adopts the view, suggested by Biggs 3P model, that the student presage factors will determine whether students adopt a deeplearning approach which is a fundamental pre-requisite to achieve the intended learning outcomes. The intended learning outcomes refer to the quantitative and qualitative product variables expected by the key stakeholders involved in this process who are HEls, students, and the government/regulators. Consequently, student presage factors are paramount for managing educational quality and should be explored by HEls in the context of a prospective quality management approach. This is in line with Gibbs $(2010,2012)$ who suggests that in order to improve educational quality and student experience, there is the need to explore student related variables.

In the context of service quality, our framework suggests that HEIs should aim to prospectively explore student expectations about service quality at the beginning of the educational process at different locations of programme delivery. This would allow to identify any unrealistic student expectations early in the process and seek to actively adjust them. As existing research indicates (Bolton and Nie 2010), student expectations and perceptions about service quality in a TNE context may vary due to social, cultural, and other local factors (i.e. education system, prevailing teaching methods). Thus, the perceived student experience by students who study at different locations can vary as result of the indifferent initial expectations and conceptualisation of service quality. HEls can address this by seeking to identify, and understand the local context that shapes student expectations and perceptions about service quality. Such understanding is a key precursor of achieving the desired learning outcomes and, as a result, the product outcomes (e.g. qualitive and quantitative) would be in line with expectations of the various stakeholders (e.g. HEls, students, regulators). Additionally, considering the positive relationship between student performance and student satisfaction, there is the prospect for an improved perceived student experience by students. Similarly, by being able to identify and manage unrealistic expectations early, HEls will be more likely to minimise the gap between expected and perceived experience by students. 
Student presage factors, including expectations about service quality, are individual and context-bound at different locations of delivery.
Student perceptions about quality in higher education are different across different locations of delivery. Perceptions about student experience will be affected by the outcomes (product) of the educational process.

\section{A prospective approach}

- Explore and identify student presage factors at the start of the education process

- Design and adjust the teaching context according to the student presage factors

- Identify and manage student expectations

- Understand how students perceive the term quality in higher education

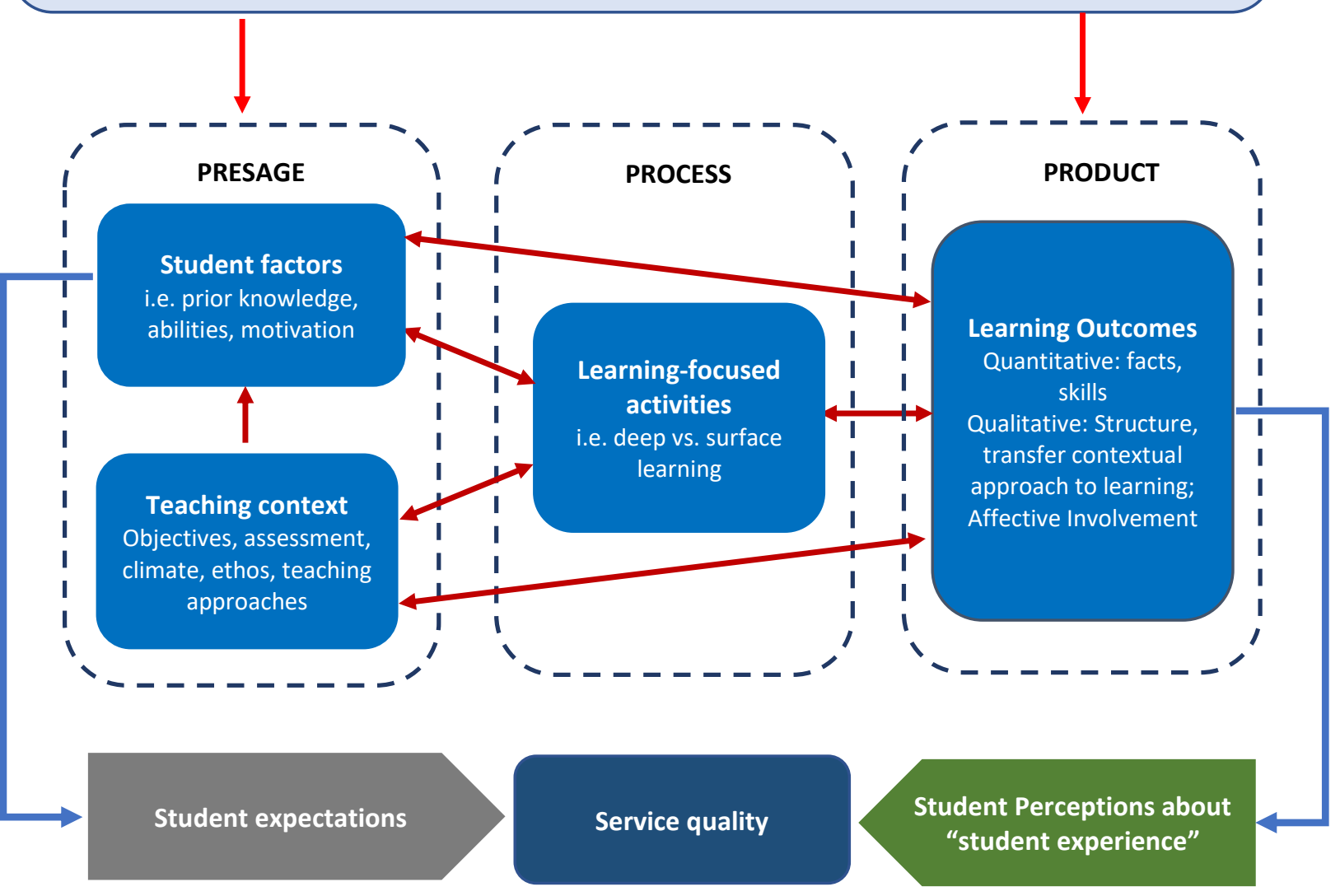

Anticipated results:

An alignment of student experience and educational quality

The teaching/learning context is designed/modified according to student presage

factors

Students are more likely to adopt a deep learning approach

The product outcomes are more likely to be in line with the expectations

Unrealistic student expectations are actively managed and adjusted

Bridging student expectations and perceptions about quality becomes more possible

Figure 5: Conceptual framework: A prospective model for managing quality in TNE 
The value of the proposed conceptual emerges from its potential applicability to TNE provision, as well as the home campus settings. With increased numbers of international students and students from non-standard entry routes, the variability of student presage factors is also evident at the home campus. Also, the proposed conceptual framework can be adopted by HEls irrespective of the institutional approach towards the student as customer discourse.

\section{Conclusions}

From the emerging conceptual model, it is clear that exploring and understanding student presage factors, and particularly their expectations and perceptions about quality, is an issue of vital importance for quality management in TNE. It is evident that if students at different delivery locations of the same programme have varying expectations about higher education quality, the applicability and effectiveness of a common retrospective customer model in a TNE context would lead to significant ramifications for service and educational quality.

Finally, reflecting on the findings from this discussion, we propose a conceptual model as an alternative for the management of quality in TNE. This model has a reflective focus on understanding and actively managing student presage factors in the context of the prospective management model of Biggs (2001) and in relation to educational quality and student experience.

Although the applicability of the proposed conceptual model requires further investigation, particularly in the context of the realised outcomes (e.g. alignment of educational quality and student experience), it can be used by managers in TNE, both at home and host institutions, to facilitate improvements in the TNE student experience while at the same time, meet wider institutional objectives about educational quality. 


\section{References}

Abdullah, F. 2006. "Measuring Service Quality in Higher Education: Three Instruments Compared." International Journal of Research \& Method in Education 29 (1): 71-89. doi:10.1080/01406720500537445.

Appleton-Knapp, S., and K. Krentler. 2006. "Measuring Student Expectations and Their Effects on Satisfaction: The Importance of Managing Student Expectations." Journal of Marketing Education 28 (3): 254-64. doi:10.1177/0273475306293359.

Arambewela, R. and J. Hall. 2006. "A Comparative Analysis of International Education Satisfaction Using Servqual." Journal of Services Research 6 (3): 141-163.

Athiyaman, A. 1997. "Linking Student Satisfaction and Service Quality Perceptions: The Case of University Education." European Journal of Marketing 31 (7): 528-540.

Balloo, K., R. Pauli, and M. Worrell. 2017. “Undergraduates' Personal Circumstances, Expectations and Reasons for Attending University." Studies in Higher Education 42 (8): 1373-84. doi:10.1080/03075079.2015.1099623.

Barnes, B. R. 2007. "Analysing Service Quality: The Case of Post-Graduate Chinese Students." Total Quality Management \& Business Excellence 18 (3): 313-31. doi:10.1080/14783360601152558.

Bebko, C. P. 2000. "Service Intangibility and Its Impact on Consumer Expectations of Service Quality." Journal of Services Marketing 14: 9-26. doi:10.1108/08876040010309185.

Biggs, J. 1988. "Assessing Student Approaches to Learning." Australian Psychologist 23 (2): 197-206. doi:10.1080/00050068808255604.

- - . 1989. "Approaches to the Enhancement of Tertiary Teaching." Higher Education Research \& Development 8 (1): 7-25. doi:10.1080/0729436890080102.

- - . 1993. "From Theory to Practice: A Cognitive Systems Approach." Higher Education Research \& Development 12 (1): 73-85. doi:10.1080/0729436930120107.

- - - 1996. "Western Misconceptions of the Confucian-Heritage Learning Culture." In The Chinese Learner: Cultural, Psychological and Contextual Influences, edited by D. Watkins and J. Biggs. University of Hong Kong, Comparative Education Research Centre.

- - . 2001. "The Reflective Institution: Assuring and Enhancing the Quality of Teaching and Learning." Higher Education 41 (3): 221-38. doi:10.1023/A:1004181331049.

Biggs, J., and C. Tang. 2011. Teaching for Quality Learning at University. Berkshire: Open university press.

Bolton, D., and R Nie. 2010. "Creating Value in Transnational Higher Education: The Role of Stakeholder Management." Academy of Management Learning \& Education 9 (4): 701-14.

Brown, R., and H. Carasso. 2013. Everything for Sale? The Marketisation of UK Higher Education. London: Routledge.

Browne, J. 2010. Securing a Sustainable Future for Higher Education. London: Department for Business, Innovation, and Skills. http://www.bis.gov.uk/assets/biscore/corporate/docs/s/101208-securing-sustainable-higher-education-browne-report.pdf.

Browne, B. A., D. O. Kaldenberg, W. G. Browne, and D. J. Brown. 1998. "Student as Customer: Factors Affecting Satisfaction and Assessments of Institutional Quality." Journal of Marketing for Higher Education 8 (3): 1-14. doi:10.1300/J050v08n03_01.

Cardoso, S., T. Carvalho, and R. Santiago. 2011. "From Students to Consumers: Reflections on the Marketisation of Portuguese Higher Education." European Journal of Education 46 (2): 27184. doi:10.1111/j.1465-3435.2010.01447.x.

Chapman, A., and D. Pyvis. 2013. Enhancing Quality in Transnational Higher Education: Experiences of Teaching and Learning in Australian Offshore Programs. Plymouth: Lexington Books.

Cheng, M. 2011. "Transforming the Learner" versus "Passing the Exam": Understanding the Gap between Academic and Student Definitions of Quality'. Quality in Higher Education 17 (1): 317. doi:10.1080/13538322.2011.554634.

Coleman, D. 2003. 'Quality Assurance in Transnational Education'. Journal of Studies in International Education 7 (December): 354-78. doi:10.1177/1028315303255597. 
Cronin Jr, J., M. K. Brady, and G. Hult. 2000. 'Assessing the Effects of Quality, Value, and Customer Satisfaction on Consumer Behavioral Intentions in Service Environments'. Journal of Retailing 76 (2): 193-218. http://www.sciencedirect.com/science/article/pii/S0022435900000282.

Davies, P. 2012. "Can Governments Improve Higher Education Through "Informing Choice"?." British Journal of Educational Studies 60 (3): 261-76. doi:10.1080/00071005.2012.715626.

De la Fuente, J., M. Cardelle-Elawar, F. J. Peralta, M. D. Sánchez, J. M. Martínez-Vicente, and L. Zapata. 2011. 'Students' Factors Affecting Undergraduates' Perceptions of Their Teaching and Learning Process within ECTS Experience." Frontiers in Psychology 2. http://www.ncbi.nlm.nih.gov/pmc/articles/PMC3111137/.

Douglas, J. A., A. Douglas, R. J. McClelland, and J. Davies. 2015. “Understanding Student Satisfaction and Dissatisfaction: An Interpretive Study in the UK Higher Education Context." Studies in Higher Education 40 (2): 329-349. http://www.tandfonline.com/doi/abs/10.1080/03075079.2013.842217.

Ekström, A., S. Liu, and D. Beljulji. 2011. "Educational Service Quality in Sweden: A Perspective of Students from the BRIC Countries." BA diss., Jönköping University. http://urn.kb.se/resolve?urn=urn:nbn:se:hj:diva-15524.

Elassy, N. 2015. "The Concepts of Quality, Quality Assurance and Quality Enhancement." Quality Assurance in Education 23 (3): 250-61. doi:10.1108/QAE-11-2012-0046.

Fallshaw, E. 2003. "Overseas Partnerships-a Case Study in Quality." Paper presented at the Higher Education Research and Development Society of Australasia Annual Conference, Canterbury, New Zealand.

Farrugia, C. 2012. "International Branch Campus Quality in a Segmented Quality Assurance Environment." Sheikh Saud Bin Saqr Al Qasimi - Foundation for Policy Research 5 (September): 1-8. http://www.academia.edu/2298638/International_Branch_Campus_Quality_in_a_Segment ed_Quality_Assurance_Environment.

Filippakou, O. 2011. "The Idea of Quality in Higher Education: A Conceptual Approach." Discourse: Studies in the Cultural Politics of Education 32 (1): 15-28. doi:10.1080/01596306.2011.537068.

Finnie, R., and A. Usher. 2005. Measuring the Quality of Post-Secondary Education: Concepts, Current Practices and a Strategic Plan. Canadian Policy Research Network. https://immagic.com/eLibrary/ARCHIVES/GENERAL/CPRN_CA/C050407F.pdf

Gibbs, G. 2010. Dimensions of Quality. York: The Higher Education Academy.

- - - 2012. Implications of 'Dimensions of Quality' in a Market Environment. York: The Higher Education Academy. http://www.heacademy.ac.uk/resources/detail/evidence_informed_practice/Implications_o f_Dimensions_of_quality.

Gibson, A. 2010. "Measuring Business Student Satisfaction: A Review and Summary of the Major Predictors." Journal of Higher Education Policy \& Management 32 (3): 251-59.

Ginns, P., M. Prosser, and S. Barrie. 2007. "Students' Perceptions of Teaching Quality in Higher Education: The Perspective of Currently Enrolled Students." Studies in Higher Education 32 (5): 603-15. doi:10.1080/03075070701573773.

Green, P. 2014. "Measuring Service Quality In Higher Education: A South African Case Study." Journal of International Education Research; Littleton 10 (2): 131.

Gruber, T., S. Fuß, R. Voss, and M. Gläser-Zikuda. 2010. "Examining Student Satisfaction with Higher Education Services: Using a New Measurement Tool." International Journal of Public Sector Management 23 (2): 105-123.

Gyimah, S. 2018. "A Revolution in Accountability" speech given at the Office for Students launch conference. https://www.gov.uk/government/speeches/a-revolution-in-accountability.

Hall, C., W. Swart, and S. Duncan. 2012. "Balancing Customer Needs and Standards in Higher Education." Quality Approaches in Higher Education 3 (1): 2-7. 
Harvey, L. 2012. "Analytic Quality Glossary." Quality Research International. http://www.qualityresearchinternational.com/glossary/internationalisation.htm.

Hill, F. M. 1995. "Managing Service Quality in Higher Education: The Role of the Student as Primary Consumer." Quality Assurance in Education 3 (3): 10-21. doi:10.1108/09684889510093497.

Hill, Y., L. Lomas, and J. MacGregor. 2003. "Students' Perceptions of Quality in Higher Education." Quality Assurance in Education 11 (1): 15-20. doi:10.1108/09684880310462047.

Hussain, K., and C. Birol. 2011. "The Assessment of Non-Academic and Academic Service Quality in Higher Education." Egitim Arastirmalari-Eurasian Journal of Educational Research, 11(42), 95-116.

Hussey, T., and P. Smith. 2010. The Trouble with Higher Education: A Critical Examination of Our Universities. Abingdon: Taylor \& Francis.

IIEP-UNESCO. 2011. Regulating and Assuring the Quality of Cross-Border Providers of Higher Education. Paris: International Institute for Educational Planning (UNESCO). http://www.iiep.unesco.org/fileadmin/user_upload/Cap_Dev_Training/Training_Materials/ HigherEd/EQA_HE_5.pdf.

Jarvis, D. 2014. "Regulating Higher Education: Quality Assurance and Neo-Liberal Managerialism in Higher Education-A Critical Introduction." Policy and Society 33 (3): 155-166.

Jungblut, J., M. Vukasovic, and B. Stensaker. 2015. "Student Perspectives on Quality in Higher Education." European Journal of Higher Education 5 (2): 157-180.

Kay, J., E. Dunne, and J. Hutchinson. 2010. Rethinking the Values of Higher Education-Students as Change Agents?. Gloucester: The Quality Assurance Agency for Higher Education.

Letcher, D. W., and J. S. Neves. 2010. "Determinants of Undergraduate Business Student Satisfaction." Research in Higher Education Journal 6 (1): 1-26.

Lim, F. C. B.. 2008. "Understanding Quality Assurance: A Cross Country Case Study." Quality Assurance in Education 16 (2): 126-40. doi:10.1108/09684880810868411.

Lizzio, A., K. Wilson, and R. Simons. 2002. "University Students' Perceptions of the Learning Environment and Academic Outcomes: Implications for Theory and Practice." Studies in Higher Education 27 (1): 27-52. doi:10.1080/03075070120099359.

Lynch, K. 2006. "Neo-Liberalism and Marketisation: The Implications for Higher Education." European Educational Research Journal 5 (1): 1-17.

-- . 2015. "Control by Numbers: New Managerialism and Ranking in Higher Education." Critical Studies in Education 56 (2): 190-207. doi:10.1080/17508487.2014.949811.

Maringe, F., and S. Carter. 2007. "International Students' Motivations for Studying in UK HE: Insights into the Choice and Decision Making of African Students." International Journal of Educational Management 21 (6): 459-475.

Milisiunaite, I., R. Adomaitiene, and J. Galginaitis. 2009. "Quality Management as a Tool for Quality Culture Embedment: Vilnius University Approach." Paper presented at the $31^{\text {st }}$ Annual EAIR Forum in Vilnius, Lithuania, August 23-26.

Milliken, J., and G. Colohan. 2004. "Quality or Control? Management in Higher Education." Journal of Higher Education Policy and Management 26 (3): 381-91. doi:10.1080/1360080042000290221.

Min, S., C. C. Khoon, and B. L. Tan. 2012. "Motives, Expectations, Perceptions and Satisfaction of International Students Pursuing Private Higher Education in Singapore." International Journal of Marketing Studies 4 (6): p122. doi:10.5539/ijms.v4n6p122.

Molesworth, M., R. Scullion, and L. Nixon. 2010. The Marketisation of Higher Education and The Student As Consumer. Abingdon: Routledge.

Moogan, Y. J., and S. Baron. 2003. "An Analysis of Student Characteristics within the Student Decision Making Process." Journal of Further and Higher Education 27 (3): 271-87. doi:10.1080/0309877032000098699.

Naidoo, R., and J. Williams. 2015. "The Neoliberal Regime in English Higher Education: Charters, Consumers and the Erosion of the Public Good." Critical Studies in Education 56 (2): 208-23. doi:10.1080/17508487.2014.939098. 
Nijhuis, J. 2006. "Learning Strategies, Student's Characteristics and Their Perceptions of the Learning Environment an Integrated Study among Business Students." PhD diss., Universiteit Maastricht.

OECD. 2009. Review on Quality Teaching in Higher Education. Institutional Management in Higher Education.

Politt, C., and G. Baichaert. 1995. 'Quality Improvements in European Public Services, Cases and Commentary'. https://www.oecd.org/education/imhe/44058352.pdf

Pratasavitskaya, H., and B. Stensaker. 2010. "Quality Management in Higher Education: Towards a Better Understanding of an Emerging Field." Quality in Higher Education 16 (1): 37-50. doi:10.1080/13538321003679465.

Quinn, A., G. Lemay, P. Larsen, and D. Johnson. 2009. "Service Quality in Higher Education." Total Quality Management \& Business Excellence 20 (2): 139-52. doi:10.1080/14783360802622805.

Sadeh, E., and M. Garkaz. 2015. "Explaining the Mediating Role of Service Quality between Quality Management Enablers and Students' Satisfaction in Higher Education Institutes: The Perception of Managers." Total Quality Management \& Business Excellence 26 (11-12): 1335-56. doi:10.1080/14783363.2014.931065.

Sander, P., K. Stevenson, M. King, and D. Coates. 2000. “University Students' Expectations of Teaching." Studies in Higher Education 25 (3): 309. doi:10.1080/03075070050193433.

Sheth, J. N., B. Mittal, and B. Newman. 1999. Consumer Behavior and Beyond. NY: Harcourt Brace.

Smimou, K., and D. W. Dahl. 2012. "On the Relationship Between Students' Perceptions of Teaching Quality, Methods of Assessment, and Satisfaction." Journal of Education for Business 87 (1): 22-35. doi:10.1080/08832323.2010.550339.

Smith, K. 2010. "Assuring Quality in Transnational Higher Education: A Matter of Collaboration or Control?." Studies in Higher Education 35 (7): 793-806. doi:10.1080/03075070903340559

Stella, A. 2006. "Quality Assurance of Cross-border Higher Education." Quality in Higher Education 12 (3): 257-76. doi:10.1080/13538320601072859.

Stella, A., and S. Bhushan. 2011. Quality Assurance of Transnational Higher Education: The Experiences of Australia and India. Australian Universities Quality Agency and the National University of Educational Planning and Administration.

Stukalina, Y. 2012. "Addressing Service Quality Issues in Higher Education: The Educational Environment Evaluation from the Students' Perspective." Technological \& Economic Development of Economy 18 (1): 84-98.

Tam, M. 2001. "Measuring Quality and Performance in Higher Education." Quality in Higher Education 7 (1): 47-54. doi:10.1080/13538320120045076.

Telford, R., and R. Masson. 2005. "The Congruence of Quality Values in Higher Education." Quality Assurance in Education 13 (2): 107-119. doi:10.1108/09684880510594364.

Tsiligiris, V. 2015. "Cross-Border Higher Education and Quality Management." PhD diss., Birmingham City University. http://ethos.bl.uk/OrderDetails.do?did=1\&uin=uk.bl.ethos.638451.

Tsoukatos, E., and G. K. Rand. 2007. "Cultural Influences on Service Quality and Customer Satisfaction: Evidence from Greek Insurance." Managing Service Quality 17 (4): 467-85. doi:10.1108/09604520710760571.

UNESCO, and Council of Europe. 2001. Code of Good Practice in the Provision of Transnational Education. Riga: Unesco-CEPES

Universities UK. 2018. The Scale of UK Higher Education Transnational Education 2016-17: Trend Analysis of HESA Data. London: UUKi.

Van der Wende, M., and D. F Westerheijden. 2001. "International Aspects of Quality Assurance with a Special Focus on European Higher Education." Quality in Higher Education 7 (3): 233-246.

Wallace, M., and L. Dunn. 2013. Teaching in Transnational Higher Education: Enhancing Learning for Offshore International Students. New York: Taylor \& Francis.

Wiers-Jenssen, J., and B. Stensaker. 2002. "Student Satisfaction: Towards an Empirical Deconstruction of the Concept." Quality in Higher Education 8 (2): 183-195. 
Wilkins, S., M. S. Balakrishnan, and J. Huisman. 2012. "Student Satisfaction and Student Perceptions of Quality at International Branch Campuses in the United Arab Emirates." Journal of Higher Education Policy and Management 34 (5): 543-56. doi:10.1080/1360080X.2012.716003.

Williams, J. 2012. Consuming Higher Education: Why Learning Can't Be Bought. London: Bloomsbury Academic.

Williams, R. M. 2018. Quality Assurance in Transnational Education. DBA diss., Bath: University of Bath.

Zajda, J., and V. Rust. 2016. 'Current Research Trends in Globalisation and Neo-Liberalism in Higher Education'. In Globalisation and Higher Education Reforms, edited by J. Zajda and V. Rust, 119. Globalisation, Comparative Education and Policy Research. Cham: Springer International Publishing. doi:10.1007/978-3-319-28191-9_1.

Zeithaml, V. A., L. L. Berry, and A. Parasuraman. 1993. "The Nature and Determinants of Customer Expectations of Service." Journal of the Academy of Marketing Science 21 (1): 1-12.

Zhao, X. 2012. "A Review on Service Quality and Student Satisfaction of Higher Education." In Soft Computing in Information Communication Technology, edited by J. Luo, 158:115-22. Berlin, Heidelberg: Springer Berlin Heidelberg.

http://link.springer.com.ezproxy.liv.ac.uk/content/pdf/10.1007\%2F978-3-642-29148-7_17. 